\title{
KONTRIBUSI PEMANFAATAN APLIKASI LEARNING MANAGEMENT SYSTEM TERHADAP KEPUASAN BELAJAR MAHASISWA PADA MATA KULIAH PEMROGRAMAN WEB (STUDI KASUS PADA MAHASISWA JURUSAN TEKNIK INFORMATIKA ITP)
}

\author{
Irsyadunas \\ Dosen Pendidikan Informatika STKIP PGRI Sumbar \\ Jl. Gunung Pangilun No. 02, Padang \\ Email : unasirsyad@gmail.com
}

Submitted: 02-01-2018, Reviewed: 06-01-2018, Accepted 10-01-2018

http://dx.doi.org/10.22202/jei.2017.v4i2.2815

\begin{abstract}
ABSTRAK
Penelitian ini dilatarbelakangi masalah belum puasnya dalam belajar mahasiswa Jurusan Teknik Informatika ITP. Jenis penelitian ini adalah penelitian korelasional.Tujuan penelitian ini untuk mengungkap seberapa besar kontribusi pemanfaatan aplikasi learning management system terhadap kepuasan belajar mahasiswa. Populasi penelitian ini berjumlah 146 orang dan sampel berjumlah 59 orang mahasiswa Jurusan Teknik Informatika ITP. Teknik pengambilan sampel dilakukan secara teknik penarikan Nonprobability Sampling Design yaitu dengan teknik sampling insidental. Sampling incidental adalah teknik penentuan sampel berdasarkan kebetulan, yaitu siapa saja yang secara kebetulan bertemu dengan peneliti dapat digunakan sebagai sampel bila dipandang orang yang kebetulan ditemui itu cocok sebagai sumber data. Sedangkan data pemanfaatan aplikasi learning management system, dan kepuasan belajar dikumpulkan melalui angket yang disebar kepada mahasiswa dengan menggunakan skala Likert yang telah diuji validitas dan reliabilitasnya. Hasil analisis data menunjukkan bahwa pemanfaatan aplikasi learning management system berkontribusi secara signifikan terhadap kepuasan belajar mahasiswa Jurusan Teknik Informatika ITP sebesar 17,13\%. Jadi dapat disimpulkan bahwa Pemanfaatan Aplikasi Learning Management System Berkontribusi terhadap Kepuasan Belajar Mahasiswa Jurusan Teknik Informatika ITP.
\end{abstract}

Kata kunci: Aplikasi Learning Management System, Kepuasan Belajar Mahasiswa.

\section{ABSTRACT}

The background of this research has not been satisfied in the learning problems of students of Department of Information ITP. This type of research is correlational research. The purpose of this study was to reveal how big the contribution of use application learning management system to the satisfaction of student learning. The study population numbered 146 people and the sample amounted to 59 students of Department of Information ITP. The sampling technique 1 Diterbitkan Oleh Program Studi Pendidikan Informatika STKIP PGRI Sumbar 
performed withdrawal technique Non-Probability Sampling Design is by incidental sampling technique. Sampling is incidental sampling technique by coincidence, that anyone who by chance met with the researchers can be used as a sample if it is deemed that the person who happened to be found suitable as a data source. While the data learning motivation, learning management system application utilization and satisfaction study were collected through a questionnaire distributed to students by using a Likert scale that has been tested for validity and reliability. The result showed that the use of learning management system applications contribute significantly to student learning satisfaction ITP Department of Informatics at 23.97\%. So it can be concluded that the Utilization Learning Management System Application Contribute to Student Learning Satisfaction Department of Information ITP.

Keywords : Applications Learning Management System, Student Learning Satisfaction.

\section{PENDAHULUAN}

Kemajuan ilmu pengetahuan telah berpengaruh terhadap penggunaan alat bantu dalam proses belajar mengajar di sekolah dan lembaga-lembaga pendidikan lainnya. Kemajuan teknologi dan perkembangan pendidikan di sekolah semakin lama semakin mengalami perubahan dan mendorong berbagai usaha perubahan demi meningkatkan mutu pendidikan.

Sekarang ini, pembelajaran di Perguruan Tinggi mulai disesuaikan dengan perkembangan teknologi informasi sehingga perkembangan pesat dibidang teknologi informasi dapat mempercepat aliran ilmu pengetahuan yang menembus batas - batas dimensi ruang, birokrasi, kemampuan, dan waktu. Dengan adanya teknologi informasi maka setiap informasi yang ada di dunia ini bisa didapatkan dalam waktu yang relatif singkat. Teknologi informasi juga dipandang sebagai hal yang sangat penting dalam perluasan kesempatan belajar serta memperoleh informasi masyarakat dunia.

Dalam rangka peningkatan mutu pendidikan telah banyak usaha yang dilakukan pemerintah, seperti pembaharuan kurikulum, pengadaan sarana dan prasarana, peningkatan mutu pendidik serta kegiatan yang merangsang minat peserta didik untuk belajar. Hal ini sangat penting mengingat fungsi pendidikan telah digariskan dalam Undang-undang Pendidikan No 20 (Depdikbud, 2003).

Depertemen Pendidikan Nasional, melalui beberapa kebijakan telah melahirkan program - program pendidikan berbasis IT, seperti hadirnya Jaringan Pendidikan Nasional (Jardiknas), INHERENT (Indonesia Higher Education Network) dan beberapa program hibah lainnya. Jurusan Teknik Informatika Institut Teknologi Padang adalah salah 
satu jurusan di ITP yang memiliki tiga konsentrasi bidang keahlian yaitu Rekayasa Perangkat Lunak (RPL), Teknik Komputer dan Jaringan (TKJ), dan Multimedia (MM).

Matakuliah Pemograman Web merupakan salah satu matakuliah yang ada di jurusan Teknik Informatika sebagai matakuliah konsentrasi pada bidang keahlian Rekayasa Perangkat Lunak (RPL). Pada matakuliah Pemograman Web tersebut mahasiswa akan diajarkan cara membuat Web dengan bahasa pemograman yang mendasar seperti bahasa pemograman HTML, CSS, PHP, Javascript, Ruby dan masih banyak lagi.

Jurusan Teknik Informatika ITP matakuliah Pemograman Web ini dibuka pada semester 4 atau semester genap. Pada matakuliah pemograman Web ini ada 3 SKS yang harus dijalani mahasiswa. 1 SKS dialokasikan waktu untuk sekali pertemuan $1 \times 50$ menit perminggu. Total pertemuan pada perkuliahan Pemograman Web adalah $3 \times 50 / 150$ menit perminggu.

Jumlah pertemuan ini masih dikeluhkan oleh mahasiswa. Hal tersebut disebabkan oleh alokasi waktu pertemuan pada perkuliahan Pemograman Web ini tidak bisa dimanfaatkan dengan sebaikbaiknya seperti perkuliahan bertepatan pada tanggal merah sehingga perkuliahan ditiadakan dan kesempatan dosen untuk melaksanakan proses perkuliahan terhalang oleh beberapa hal seperti sakit, dinas keluar kota dan lain-lain.

Pada survey awal yang dilakukan pada 3 September 2014 di Jurusan Teknik Informatika Institut Teknologi Padang, diperoleh data terkait dengan fasilitas dan infrastruktur Teknologi Informasi di Jurusan Teknik Informatika Institut Teknologi Padang, seperti 1 buah labor jaringan, 2 buah labor pemograman, 4 buah hotspot yang dapat digunakan semua jurusan, 1 buah sistem informasi akademik untuk semua jurusan, 4 terminal computer yang dapat digunakan untuk mengakses internet, memiliki kamera CCTV dan LCD projector untuk setiap ruang kelas. Fasilitas ini sangat bermanfaat untuk kepentingan belajar mengajar bagi dosen dan mahasiswa. Karena dosen bisa menjelaskan serta mengukur kemampuan siswa dalam belajar dan siswa dapat secara langsung mempraktekkan semua pelajaran yang dijelaskan oleh dosen.

Namun pada kenyataannya fasilitas tersebut belum digunakan atau dimanfaatkan sesuai dengan harapan. Hal ini disebabkan karena masih banyak mahasiswa yang kurang memahami besar manfaat dari sarana teknologi informasi tersebut dan kurangnya informasi yang didapatkan mahasiswa. Salah satu contohnya ada di antara mahasiswa yang kurang bisa mengakses wifi kampus sendiri. Hal ini diperoleh peneliti dari 
pengamatan yang dilakukan secara acak kepada beberapa mahasiswa yang bertemu dengan peneliti.

Pendidikan adalah salah satu bidang yang mendapatkan dampak yang cukup berarti dengan perkembangan teknologi, dimana pada dasar pendidikan merupakan suatu proses komunikasi dan informasi dari pendidik kepada peserta didik yang berisi informasi - informasi pendidikan, yang memiliki unsur - unsur pendidik sebagai sumber informasi, media sebagai sarana penyaji ide, gagasan dan materi pendidikan serta peserta didik itu sendiri. Oetomo dan Priyogutomo dalam Mohammad Adri (2008:2). Beberapa bagian unsur ini mendapatkan sentuhan media teknologi informasi, sehingga mencetuskan lahirnya ide tentang $e$ learning.

Menurut Darin E. Hartley dalam Gartika dan Rita Rismiati (2013:27), elearning adalah merupakan suatu jenis belajar mengajar yang memungkinkan tersampaikannya bahan ajar ke siswa dengan menggunakan media internet, intranet atau media jaringan komputer lainnya. Rusman (2013:335) mengatakan bahwa e-learning adalah aplikasi teknologi web dalam dunia pembelajaran untuk sebuah proses pendidikan.

Menurut Agus Lukman Hakim, Munzil dan Parlan (2013:1-2) pembelajaran yang hanya dilakukan di kelas memiliki beberapa kelemahan, diantaranya sumber belajar terbatas, pembelajaran kurang efektif, dan tidak mampu mengakomodasi gaya dan kecepatan belajar siswa. Gaya belajar adalah suatu cara atau strategi seseorang dalam mengelola informasi. Kelemahan tersebut dapat diatasi dengan memanfaatkan perkembangan teknologi yang semakin maju dengan mengembangkan media pembelajaran yang dapat mengakomodasi perbedaan gaya dan kecepatan belajar siswa. Oleh karena itu diperlukan sebuah media yang mampu memberikan nuansa baru dalam pembelajaran, memberikan beragam sumber belajar yang dapat diakses setiap saat oleh siswa, sehingga mampu mengakomodasi gaya dan kecepatan belajar siswa. Salah satu alternatif yang diajukan adalah dengan mengembangkan media pembelajaran berbasis Learning Management System (LMS) dengan memanfaatkan kemajuan teknologi di bidang internet. Penggunaan Learning Management System (LMS) atau yang juga dikenal sebagai Virtual Learning Environtment (VLE) adalah suatu pengelolaan pembelajaran yang mempunyai fungsi untuk memberikan sebuah materi, mendukung kolaborasi, menilai kinerja siswa, merekam data peserta didik, dan menghasilkan laporan yang berguna untuk memaksimalkan 
efektivitas dari sebuah pembelajaran. LMS biasanya dikembangkan dalam sistem berbasis web. Penggunaan teknologi web ini dalam suatu program pendidikan memberikan dukungan kepada guru atau pengajar untuk mencapai tujuan pedagogis siswa, mengatur isi, dan mendukung sarana belajar siswa pada akhirnya.

Media pembelajaran berbasis learning management system menjadi salah satu solusi yang bisa dipakai dalam proses pembelajaran. Beberapa alasan menggunakan media pembelajaran ini adalah (a) terjadi peningkatan efektivitas pembelajaran dan prestasi akademik siswa, (b) menambah kenyamanan, (c) menarik lebih banyak perhatian siswa kepada materi yang disampaikan dalam pembelajaran, (d) dapat diterapkan dengan berbagai tingkat dan model pembelajaran, dan (e) dapat menambah waktu pembelajaran dengan memanfaatkan teknologi dunia maya. Media pembelajaran berbasis LMS sangat berguna dalam menyediakan lingkungan/suasana belajar yang lengkap bagi siswa, karena penuh dengan penyediaan dokumen yang terkait modul dalam format elektronik, kesempatan untuk saling belajar bersama-sama, dan kesempatan untuk menyerahkan semua penilaian sumatif secara elektronik. Alasan lain yang mendukung perspektif tersebut adalah bahwa setiap siswa memiliki akses ke semua konten pembelajaran, memiliki fleksibilitas waktu dan momen yang paling cocok untuk kebutuhan siswa dalam belajar, dapat belajar dengan kemampuan kecepatan belajar masing-masing, dan berpartisipasi dalam kesempatan belajar yang interaktif ".

LMS itu merupakan sistem perangkat lunak yang memvirtualisasi proses belajar mengajar konvensional. Bagaimana manajemen kelas, pembuatan materi dan segala fitur yang berhubungan dengan manajemen proses belajar mengajar). Konten dan bahan ajar yang ada pada $e$ - learning System (Learning Management System). Konten dan bahan ajar bisa dalam bentuk Multimedia - based Content (konten berbentuk multimedia interaktif) atau Text-based Content (Konten berbentuk teks seperti pada buku pelajaran biasa). Biasa disimpan dalam Learning Managenent System (LMS) sehingga dapat dijalankan oleh mahasiswa kapanpun dan dimanapun.

Banyak manfaat dan keuntungan yang didapat oleh mahasiswa dan dosen pada aplikasi Learning Managenent System (LMS) diantaranya tersedianya fasilitas edmodo di mana dosen dan mahasiswa dapat berkomunikasi secara mudah melalui fasilitas internet secara regular atau kapan saja dilakukan tanpa dibatasi oleh jarak, tempat, dan waktu. Baik pendidik maupun peserta didik dapat 
melakukan diskusi melalui internet yang dapat diikuti dengan jumlah peserta yang banyak sehingga menambah ilmu pengetahuan dan wawasan yang lebih luas.

Menurut Basori (2013:2) Edmodo merupakan alternatif yang dapat digunakan untuk pembelajaran online, tanpa biaya perawatan yang banyak. Di samping itu juga dibutuhkan yang user friendly, agar pengoperasiannya mudah dan tidak membingungkan bagi yang menggunakannya. Edmodo didirikan pada tahun 2008 oleh Nicolas Brog dan Jeff O'Hara. Edmodo adalah sebuah platform Microblogging yang secara khusus dikembangkan dan dirancang untuk digunakan oleh guru dan siswa yang memvirtualkan suasana dalam suatu ruang kelas.

Kepuasan merupakan keadaan emosional yang menyenangkan atau tidak menyenangkan yang ditampilkan dalam sikap positif terhadap berbagai kegiatan dan tanggapannya menghadapi lingkungan luar. Kepuasan adalah faktor utama yang mempengaruhi loyalitas mahasiswa sebagai konsumen pendidikan tinggi.

Belajar merupakan suatu proses usaha yang dilakukan individu untuk memperoleh suatu perubahan perilaku yang baru secara keseluruhan, sebagai hasil pengalaman individu itu sendiri dalam interaksi dengan lingkungannya.
Kepuasan belajar adalah sesuatu yang menyenangkan atau tidak menyenangkan dalam belajar, diperoleh setelah melakukan kegiatan belajar. Dapat berupa puas dan tidak puas setelah melakukan proses belajar.

Hamzah (2011:16) menjelaskan; “....Apabila mahasiswa belajar maka hasil dapat dilihat dari kemampuannya melakukan sesuatu kegiatan baru yang bersifat menetap dari pada yang dilakukan sebelumnya sebagai akibat atau hasil dari interaksi siswa dengan lingkungan". Seseorang yang mengalami proses belajar dapat ditandai dengan adanya perubahan prilaku sebagai suatu kriteria keberhasilan belajar pada diri seseorang yang belajar. Slameto (2010:2) menjelaskan; "Belajar adalah suatu proses usaha yang dilakukan baru secara keseluruhan, sebagai hasil pengalamannya sendiri dalam interaksi dengan lingkungannya.

Pada survey yang dilakukan kepada mahasiswa Institut Teknologi Padang (ITP) bernama Setiawan Rendi Putra dan Rozali Ilham Bp 2011 Jurusan Teknik Informatika mengungkapkan dosen yang bernama bapak Rahmat Hidayat ST, M.Sc,IT pada perkuliahan Pemograman Web di kampusnya mengunakan aplikasi Learning Management System khususnya Edmodo.

Berdasarkan hasil keterangan mahasiswa tersebut peneliti segera 
melakukan wawancara kepada dosen pembina matakuliah tersebut. Beliau mengungkapkan bahwa penggunaan media LMS yaitu Edmodo merupakan salah satu alternative pembelajaran yang mudah difahami oleh mahasiswa karena tampilannya tidak jauh beda dengan media social facebook dan efisien. Faktor yang mendorong beliau melakukan hal tersebut adalah yang pertama karena menurut beliau keterbatasan waktu pertemuan dengan banyak materi pada matakuliah Pemograman Web tersebut. Keterbatasan tersebut dapat dikarenakan oleh hari libur nasional yang bertepatan dengan jadwal perkuliahan, dinas keluar kota dan lainlain. Yang kedua adalah adanya perbedaan kemampuan setiap mahasiswa dalam menyerap pelajaran yang diberikan dosen.

Sesuai dengan lingkup penelitian yakni faktor yang mempengaruhi kepuasan belajar adalah pemanfaatan Aplikasi Learning Management System. Keseluruhan faktor ini, mempunyai kaitan yang erat antara satu dengan yang lainnya, dan diduga sangat berpengaruh terhadap hasil belajar. Dalam penelitian ini meneliti Pemanfaatan Aplikasi Learning Management System sebagai variabel bebas (X) dan Kepuasan belajar sebagai variabel terikat $(\mathrm{Y})$. Gambar 1 berikut menjelaskan tentang skema kerangka konseptual.

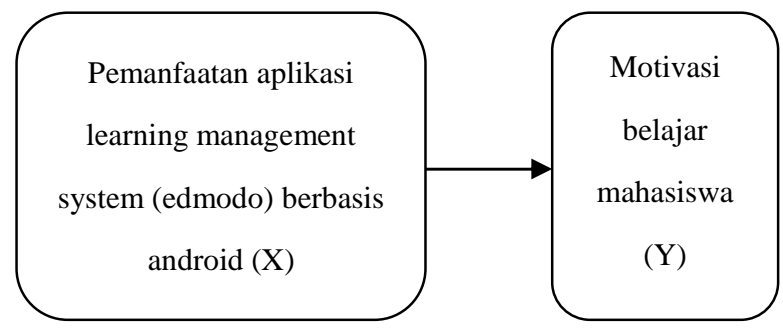

Gambar 1.Kerangka Konseptual

2. JUDUL

KOTRIBUSI PEMANFAATAN APLIKASI

MANAGEMENT

LEARNING

TERHADAP KEPUASAN BELAJAR

MAHASISWA PADA MATA KULIAH

PEMROGRAMAN WEB ( Studi Kasus

Pada Jurusan Teknik Informatika ITP )

\section{METODE PENELITIAN}

Jenis penelitian ini adalah penelitian deskriptif korelasional. Menurut Arikunto (1998:251) Desktriptif korelasional adalah suatu penelitian yang dirancang untuk menentukan tingkat hubungan variabelvariabel yang berbeda dalam suatu populasi yang bertujuan untuk mengetahui seberapa besar pengaruh variabel $(\mathrm{X})$ terhadap variabel (Y) serta bentuk hubungan yang terjadi.

Penelitian ini bertujuan untuk mengetahui kontribusi pemanfaatan aplikasi learning management system (X) terhadap kepuasan belajar mahasiswa (Y).

Penelitian ini di awali dengan mengetahui permasalahan objek penelitian 
yang akan diteliti, yaitu untuk mengetahui apakah ada hubungan antara kepuasan belajar dengan aplikasi learning management system. Setelah mengetahui permasalahan maka dilakukan studi literatur dan wawancara untuk mencari teori-teori yang dapat dijadikan sebagai acuan untuk memulai penelitian, serta mencari jurnal-jurnal yang berhubungan dengan topik penelitian ini.

Setelah itu dilanjutkan dengan membuat model penelitian dengan menggunakan variabel-variabel terikat. Setelah dibuat model penelitian, maka dilakukan penyebaran kuisioner uji coba untuk mengetahui validitas dan realibilitas. Kusioner yang sudah valid, kemudian melakukan penyebaran kuisioner valid untuk menguji korelasi, regresi dan gambaran analisis. Dengan hasil yang diperoleh, maka penulis mengambil kesimpulan dan mengajukan saran atas penelitian ini.

Berikut ini gambaran dari alur penelitian secara keseluruhan pada gambar dibawah ini:

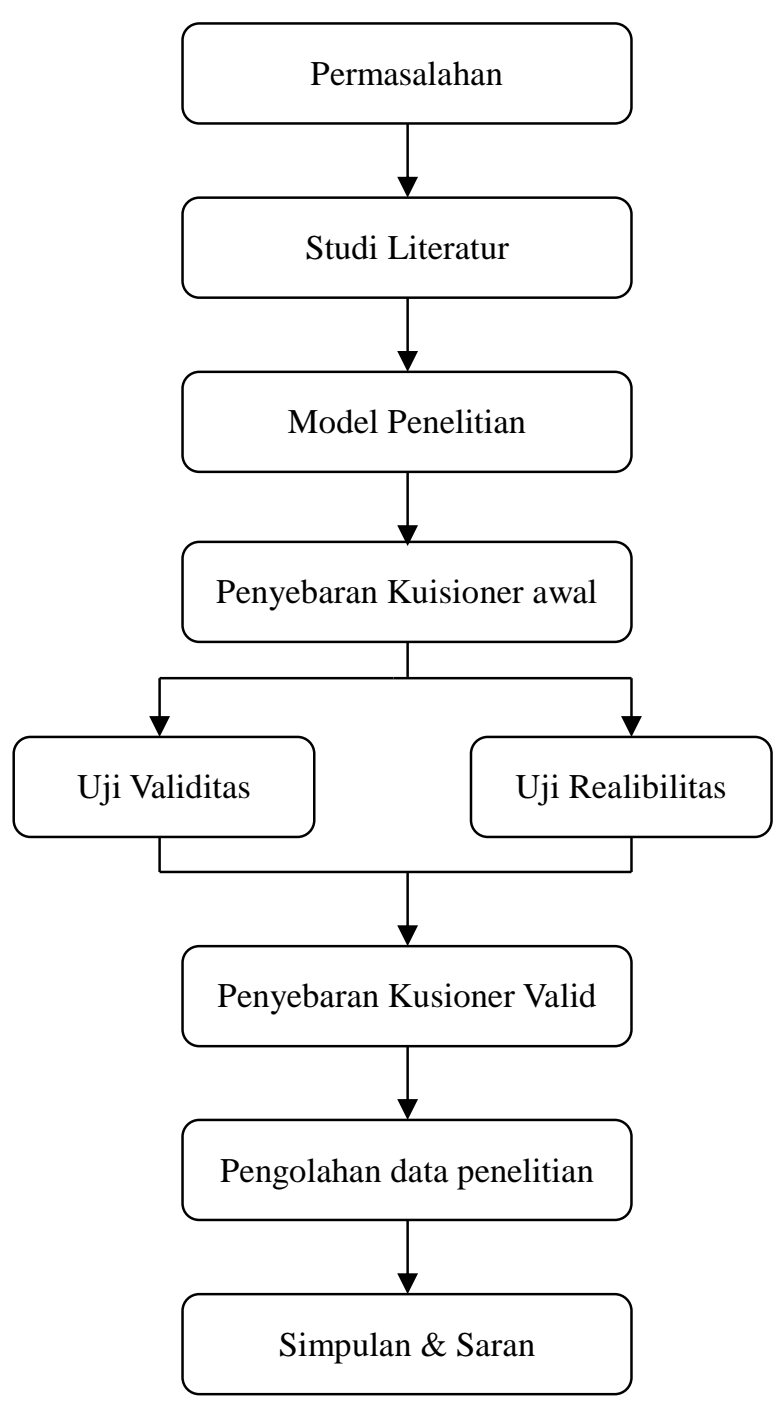

Gambar 2 . Alur penelitian

1. Variabel dan data penelitian

Dalam penelitian ini dapat dilihat ada dua variable, satu variabel terikat dan satu variable bebas. Variabel terikat adalah Kepuasan Belajar Mahasiswa (Y). Variabel bebas adalah pemanfaatan Aplikasi Learning Management System (X). 
Menurut Arikunto (1998: 99) data adalah " hasil pencatatan peneliti, baik yang berupa fakta ataupun angka". Sumber data yang dipakai dalam penelitian ini adalah Mahasiswa Teknik Informatika Bp 2011 yang mengambil matakuliah Pemograman Web bersama dosen pembimbing bapak Rahmat Hidayat ST, Msc, IT.

Untuk penelitian ini teknik pengumpulan data yang peneliti gunakan dalam penelitian ini adalah berupa penyebaran kuesioner kepada Mahasiswa Teknik Informatika Bp 2011 yang mengambil matakuliah Pemograman Web bersama dosen pembimbing bapak Rahmat Hidayat ST, Msc, IT. Agar penelitian lebih valid diperlukan juga pemberian kuisioner kepada dosen pembimbing matakuliah Pemograman Web sebagai element educator. Menurut Arikunto (1998: 140) "Angket atau kuisioner adalah sejumlah pernyataan tertulis yang digunakan untuk memperoleh informasi dari responden dalam arti laporan tentang pribadinya atau hal-hal yang ia ketahui".

2. Populasi dan Sampel Penelitian

Sugiyono (2007:80) menyatakan bahwa 'Populasi adalah wilayah generalisasi yang terdiri atas objek/subjek yang mempunyai kualitas dan karakteristik tertentu yang ditetapkan oleh peneliti untuk dipelajari dan kemudian ditarik kesimpulannya'. Menurut Arikunto (2010:173) Populasi adalah keseluruhan subjek penelitian. Apabila seseorang ingin meneliti semua elemen yang ada dalam wilayah penelitian, maka penelitinya merupakan penelitian populasi.

Arikunto (2010:174) menyatakan bahwa "Sampel adalah sebahagian atau wakil populasi yang diteliti”. Sugiyono (2013:120) menjelaskan bahwa "'Sampel adalah bagian dari jumlah dan karakteristik yang dimiliki oleh populasi”'.

3. Tempat Penelitian

Penelitian ini dilakukan di Jurusan Teknik Informatika Institut Teknologi Padang yang bertempat di Kota Padang Provinsi Sumatera Barat.

4. Instrumen Penelitian

Menurut Suharsimi Arikunto (2002: 136), Instrumen penelitian merupakan alat atau fasilitas yang digunakan oleh peneliti dalam mengumpulkan data penelitian". Dalam penelitian ini, instrumen yang digunakan yaitu angket atau kuesioner yang disebar kepada Mahasiswa Teknik Informatika Bp 2011 yang mengambil matakuliah Pemograman Web dengan dosen pembimbing mata kuliah tersebut. 


\section{Uji Coba Instrumen}

Uji coba instrumen dilakukan dengan maksud untuk mengetahui apakah instrumen yang digunakan teruji tingkat validitas (keshahihannya) dan Reliabilitas (keterhandalannya). Validitas instrumen adalah kemampuan suatu alat ukur untuk mengukur apa yang harus diukur sesuai dengan standarnya. Sedangkan Reliabilitas adalah kemampuan suatu alat ukur untuk memberikan hasil pengukuran yang konsisten dalam waktu dan tempat yang berbeda, juga untuk mengetahui pemahaman responden terhadap butir - butir pernyataan.

6. Teknik analisis

a. Deskripsi data

Pendeskripsian data dilakukan untuk menentukan kedudukan data dalam suatu kelompok. Pendeskripsian bertujuan untuk mengungkapkan mean, modus, median, dan standar deviasi guna mengetahui gambaran tentang sebaran data serta tingkat pencapaian.

b. Pengujian prasyarat analisis

$$
\text { Uji normalitas, uji }
$$
homogenitas, uji linearitas, uji multikolinearitas.

c. Analisis regresi berganda

d. Pengujian hipotesis.

\section{HASIL DAN PEMBAHASAN}

Data penelitian ini meliputi 3 variabel yaitu, Kontribusi Pemanfaatan Aplikasi Learning Management System (X), dan Kepuasan Belajar Mahasiswa (Y). Deskripsi data menggambarkan data-data penelitian tentang jumlah data, mean, median, modus, range, nilai minimum, nilai maksimum, standar deviasi, dan varians yang diperoleh.

1. Pengujian Instrumen

a. Analisis Uji Validitas

Kriteria pengujian diambil berdasarkan perbandingan nilai $r_{\text {hitung dengan }} r_{\text {tabel }}$. Jika thitung $\geq$ $t_{\text {tabel, }}$ maka data valid sebaliknya jika $t_{\text {hitung }} \leq t_{\text {tabel}}$, maka data tidak valid. Diketahui $\mathrm{n}=20, \alpha=$ 5\%. pada tabel $\mathrm{t}=0,444$ untuk mahasiswa.

Kesimpulan: dengan membandingkan thitung dengan

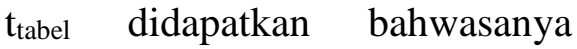
untuk variabel $\mathrm{X}$, dan $\mathrm{Y}$. Berdasarkan hasil uji coba instrumen yang telah dilaksanakan kepada 20 orang mahasiswa BP 2011 yang mengambil mata kuliah Pemograman Web.

Khusus untuk angket pemanfaatan aplikasi learning management system, kevalidan masing-masing item juga harus 
diperkuat dengan pernyataan dari angket dosen. Hal itu karena dosen sebagai element instruktur sangat berperan penting dalam pemanfaatan aplikasi learning management system.

b. Analisis Uji Realibilitas

Tabel 1 merupakan ringkasan hasil uji realibilitas instrumen penelitian:

Tabel 1. Ringkasan Hasil Uji Reliabilitas Instrumen Penelitian

\begin{tabular}{|c|c|c|c|c|c|}
\hline $\begin{array}{l}\text { Variabe } \\
1\end{array}$ & $\begin{array}{l}\text { Nilai } \\
\text { Relia } \\
\text { bilitas } \\
\left(\mathrm{r}_{11}\right) \\
\end{array}$ & $\mathrm{r}_{\text {tabel }}$ & $\begin{array}{l}\text { kondi } \\
\text { si }\end{array}$ & $\begin{array}{l}\text { simpu } \\
\text { lan }\end{array}$ & $\begin{array}{l}\text { Keteran } \\
\text { gan }\end{array}$ \\
\hline $\begin{array}{l}\text { Pemanf } \\
\text { aatan } \\
\text { Aplikas } \\
\text { i }\end{array}$ & & & & & \\
\hline $\begin{array}{l}\text { Learnin } \\
\text { g } \\
\text { Manag } \\
\text { ement } \\
\text { System }\end{array}$ & 0,913 & 0.444 & $\begin{array}{l}r_{11} \geq \\
r_{\text {tabel }}\end{array}$ & $\begin{array}{l}\text { Relia } \\
\text { bel }\end{array}$ & $\begin{array}{l}\text { Sangat } \\
\text { tinggi }\end{array}$ \\
\hline $\begin{array}{l}\text { Kepuas } \\
\text { an } \\
\text { Belajar }\end{array}$ & 0,937 & 0.444 & $\begin{array}{l}\mathrm{r}_{11} \geq \\
\mathrm{r}_{\text {tabel }}\end{array}$ & $\begin{array}{l}\text { Relia } \\
\text { bel }\end{array}$ & $\begin{array}{l}\text { Sangat } \\
\text { tinggi }\end{array}$ \\
\hline
\end{tabular}

Berdasarkan hasil uji coba instrumen yang dilaksanakan kepada 20 orang mahasiswa, diperoleh hasil perhitungan reliabilitas variabel Kontribusi
Pemanfaatan Aplikasi Learning Management System (X) sebesar 0,913 dan variabel Kepuasan Belajar Mahasiswa (Y) sebesar 0,937 . Hal ini menunjukkan bahwa instrumen-instrumen tersebut mempunyai tingkat keterandalan yang memenuhi syarat sebagai alat pengumpulan data dalam penelitian.

2. Deskripsi Data

a. Pemanfaatan Aplikasi Learning Managemnt Sytem.

Data variabel pemanfaatan aplikasi learning management system dikumpulkan melalui angket yang terdiri dari 16 butir pernyataan yang telah diuji validitas dan reliabilitasnya. Selanjutnya angket diberikan kepada 59 orang responden untuk diisi. Perhitungan statistik dasar variabel perilaku belajar mahasiswa dalam pemanfatan Aplikasi Learning Management System terdapat pada Tabel dibawah ini.

Tabel 2. Hasil Perhitungan Statistik Pemanfaatan Aplikasi Learning Management System

\begin{tabular}{lc|r}
\hline & & \multicolumn{1}{|c}{ X2 } \\
\hline N $\quad$ Valid & 59 \\
\multicolumn{2}{l|}{ Missing } & 0 \\
\multicolumn{2}{l|}{ Mean } & 68.63 \\
\hline
\end{tabular}




\begin{tabular}{|c|c|}
\hline Median & 69.00 \\
\hline Mode & 70 \\
\hline Std. Deviation & 4.877 \\
\hline Variance & 23.790 \\
\hline Range & 22 \\
\hline Minimum & 57 \\
\hline Miximum & 79 \\
\hline Sum & 4049 \\
\hline
\end{tabular}

Tabel dapat dilihat bahwa variabel pemanfaatan aplikasi learning management system $\mathrm{X}$ dengan jumlah mean 68.63 lebih kecil dari median 69.00 sehingga sebaran data condong ke kiri. Perhitungan distribusi kelas interval variabel perilaku belajar mahasiswa sebagai berikut :

1) Jarak atau Rentangan

$$
\begin{aligned}
& =\text { Nilai Max }- \text { Nilai Min } \\
& =79-57=22
\end{aligned}
$$

2) Jumlah Kelas

$$
\begin{aligned}
& =1+3.3 \log \mathrm{n} \\
& =1+3.3 \log 59 \\
& =1+3.3(1.77) \\
& =6,8 \approx 7
\end{aligned}
$$

3) Kelas Interval

$$
\begin{aligned}
& =\frac{\text { Rentangan }}{\text { Jumlah Kelas }} \\
& =\frac{22}{7}=3,2 \approx 3
\end{aligned}
$$

Tabel 3. Distribusi Frekuensi Skor Pemanfaatan Aplikasi Learning Management System.

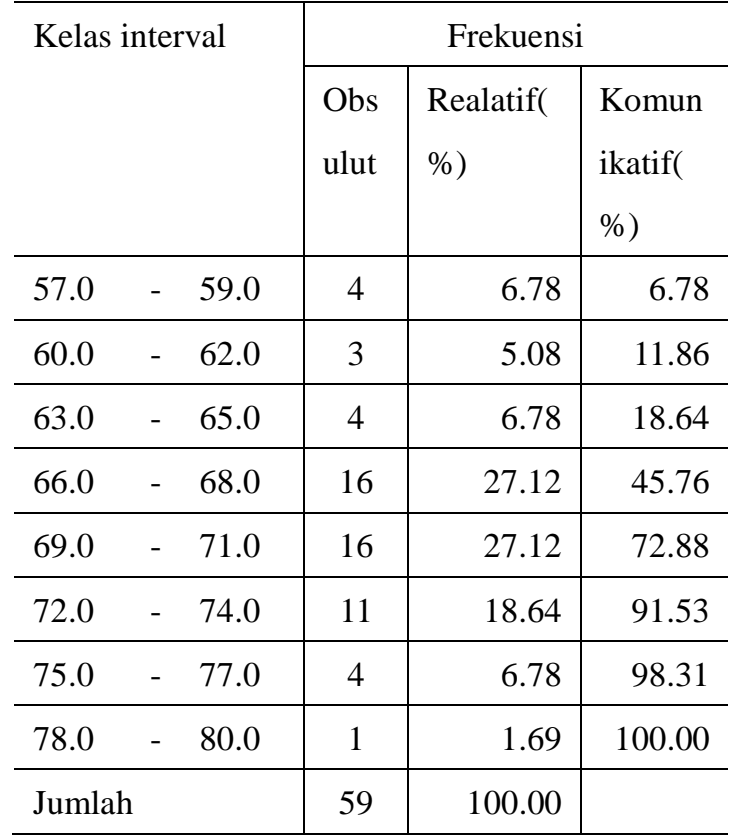

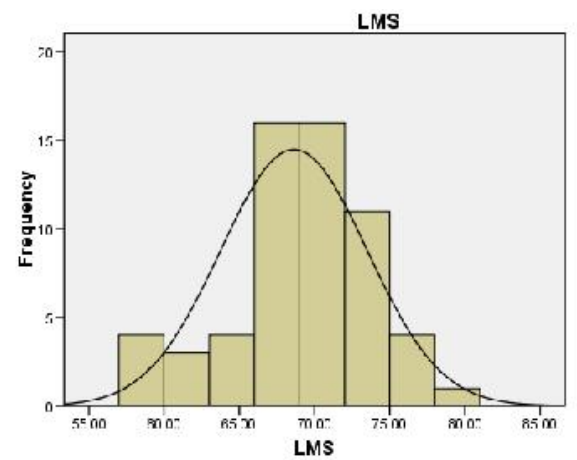

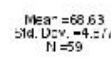

Gambar 3. Histogram Skor Pemanfaatan Aplikasi Learning Management System.

Histogram kurva normal pada Gambar 3 menunjukkan condong ke kanan, hal ini menunjukkan bahwa pemanfaatan aplikasi learning management system pada Jurusan Teknik Informatika ITP sudah dioptimalkan. 
b. Kepuasan Belajar

Data variabel kepuasan belajar mahasiswa dikumpulkan melalui angket yang terdiri dari 27 butir pernyataan yang telah diuji validitas dan reliabilitasnya. Selanjutnya angket diberikan kepada 59 orang responden untuk diisi.

Perhitungan statistik dasar variabel kepuasan belajar mahasiswa tedapat pada Tabel di bawah :

Tabel 4. Hasil Perhitungan Kepuasan Belajar Mahasiswa.

\begin{tabular}{l|r|r}
\hline & \multicolumn{1}{|c|}{ X } & \multicolumn{1}{c}{$\mathrm{Y}$} \\
\hline N Valid & 59 & 59 \\
\multicolumn{1}{c|}{ Missing } & 0 & 0 \\
Mean & 68.63 & 107.42 \\
Median & 69.00 & 108.00 \\
Mode & 70 & 108 \\
Std. Deviation & 4.877 & 9.798 \\
Variance & 23.79 & 96.007 \\
Range & 22 & 46 \\
Minimum & 57 & 80 \\
Miximum & 79 & 126 \\
Sum & 4049 & 6338 \\
\hline
\end{tabular}

Perhitungan statistik pada Tabel 4 dapat dilihat bahwa variabel kepuasan belajar mahasiswa (Y) dengan jumlah mean 107,42 lebih kecil dari median 108,00 sehingga sebaran data condong ke kiri. Perhitungan distribusi kelas interval variabel kepuasan belajar mahasiswa sebagai berikut:

1) Jarak atau Rentangan

$$
\begin{aligned}
& =\text { Nilai Max }- \text { Nilai Min } \\
& =126-80=46
\end{aligned}
$$

2) Jumlah Kelas

$$
\begin{aligned}
& =1+3.3 \log n \\
& =1+3.3 \log 59 \\
& =1+3.3(1.77) \\
& =6,8 \approx 7
\end{aligned}
$$

3) Kelas Interval

$$
\begin{aligned}
& =\frac{\text { Rentangan }}{\text { Jumlah Kelas }} \\
& =\frac{46}{7}=6,7 \approx 6
\end{aligned}
$$

Tabel 5. Distribusi Frekuensi Kepuasan Belajar Mahasiswa

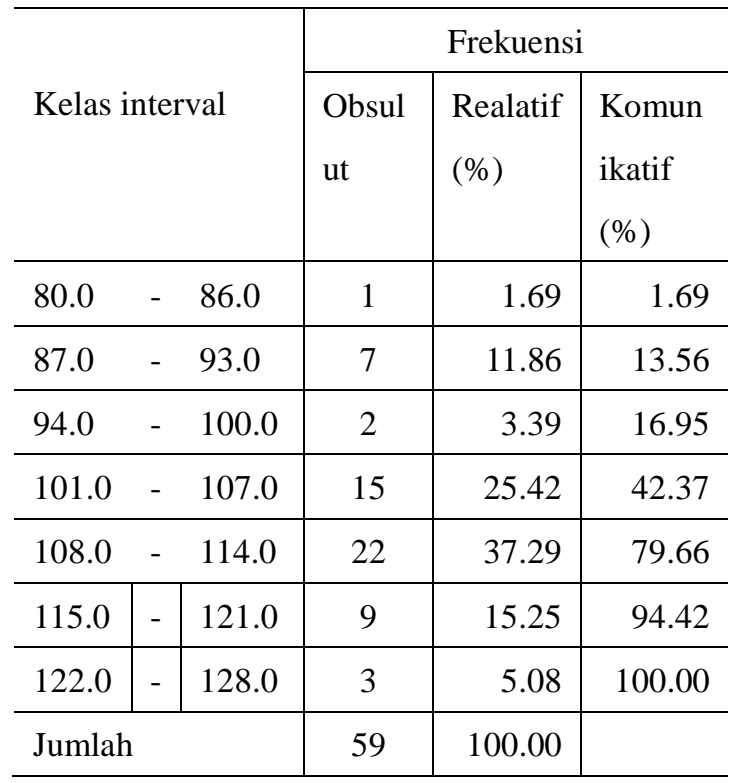




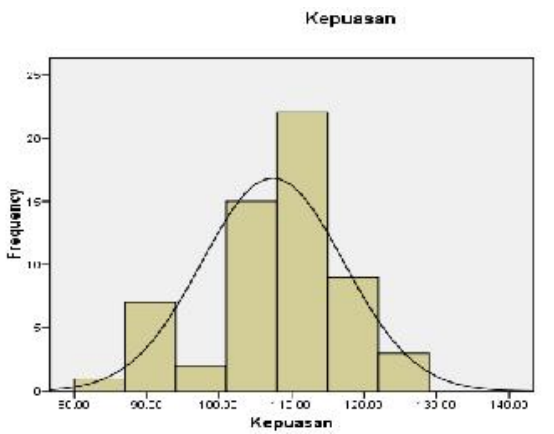

Gambar 4. Histogram

Skor Kepuasan

Mahasiswa.

Histogram kurva normal

pada Gambar diatas menunjukkan condong ke kanan, hal ini memberi arti bahwa kepuasan belajar mahasiswa pada Jurusan Teknik Informatika ITP cenderung meningkat.

3 Pengujian prasyarat analisis

a. Uji Normalitas

Uji normalitas bertujuan untuk mengetahui apakah data terdistribusi secara normal atau tidak. Uji normalitas yang digunakan adalah dengan uji Lilliefors dengan melihat nilai pada Kolmogorov-Smirnov. Hasil perhitungan uji normalitas dapat dilihat pada rangkuman Tabel dibawah ini.
Tabel 6. Uji normalitas

\begin{tabular}{|c|c|c|c|}
\hline & & $\mathrm{X}$ & $\mathrm{Y}$ \\
\hline \multicolumn{2}{|l|}{$\mathrm{N}$} & 59 & 59 \\
\hline \multirow{2}{*}{\multicolumn{2}{|c|}{ Normal Parameters ${ }^{\mathrm{ab}}$ Mean }} & 68.63 & 107.4 \\
\hline & & 4.877 & 2 \\
\hline \multicolumn{2}{|l|}{ Std.Deviation } & 115 & 9.798 \\
\hline Most Extreme & Absolute & 067 & 127 \\
\hline \multirow[t]{2}{*}{ Differences } & Positive & 115 & 065 \\
\hline & Negative & 884 & 127 \\
\hline \multicolumn{2}{|c|}{ Kolmogorow-Smirnov } & 415 & 974 \\
\hline \multicolumn{2}{|c|}{ Asymp. Sig.(2-taelid) } & & 299 \\
\hline
\end{tabular}

Dari Tabel 6 dapat dilihat bahwa skor signifikansi probabilitas untuk variabel $\mathrm{X}$ sebesar 0,415 dan variabel Y sebesar 0,299.

b. Uji Homogenitas

Uji Homogenitas digunakan untuk mengetahui apakah beberapa varian populasi data adalah sama atau tidak. Hasil uji homogenitas data dapat dilihat pada Tabel dibawah ini.

Tabel 7. Uji Homogenitas pada Pemanfaatan

Aplikasi Learning Management System.

\begin{tabular}{l|c|c|c}
\hline $\begin{array}{l}\text { Levene } \\
\text { Statistic }\end{array}$ & df 1 & df2 & Sig \\
\hline 1.535 & 12 & 40 & 152 \\
\hline
\end{tabular}

Dari Tabel di atas didapatkan skor signifikansi pada pemanfaatan aplikasi learning management system sebesar 0,152. Jadi signifikansi lebih 
besar dari 0,05 maka dapat disimpulkan bahwa varian populasi data mahasiswa Jurusan Teknik Informatika ITP homogen.

4. Uji hipotesis

Pengujian hipotesis pertama dengan melihat nilai signifikansi.

a. Hipotesis Pertama

Hipotesis pertama adalah pemanfaatan aplikasi learning management system berkontribusi dan signifikan terhadap kepuasan belajar mahasiswa pada matakuliah Pemograman Web Jurusan Teknik Informatika ITP.

$$
\begin{aligned}
& R^{2}=\frac{\sum b_{2} \sum x_{2} y}{\sum y^{2}} \\
& R^{2}=\frac{(0,825)(1618)}{5568,4} \\
& R^{2}=0,2397 \\
& R=0,2397 \times 100=23,97 \%
\end{aligned}
$$

Berdasarkan data pada Tabel 12, diperoleh nilai $\mathrm{t}=3,402$ dengan signifikan 0,001 Sehingga dapat dikatakan signifikan $<0,05 \quad(0,001<$ 0,05) maka Ho ditolak, Ha diterima, artinya pemanfaatan aplikasi learning management system $(\mathrm{X})$ secara parsial berkontribusi signifikan terhadap kepuasan belajar mahasiswa (Y).

\section{SIMPULAN DAN SARAN}

1. Kesimpulan

Berdasarkan hasil penelitian yang telah dilakukan, dapat diambil kesimpulan sebagai berikut :

a. Motivasi belajar memberikan kontribusi yang signifikan sebesar $17,47 \%$ terhadap kepuasan belajar mahasiswa Jurusan Teknik Informatika ITP. Hal ini menunjukkan motivasi belajar berkontribusi terhadap kepuasan belajar.

b. Pemanfaatan aplikasi learning management system memberikan kontribusi yang signifikan sebesar 23,97\% terhadap kepuasan belajar mahasiswa Jurusan Teknik Informatika ITP. Hal ini menunjukkan pemanfaatan aplikasi learning management system berkontribusi terhadap kepuasan belajar.

2. Saran

Berdasarkan hasil penelitian dan kesimpulan maka dapat diberikan saran-saran sebagai berikut:

a. Variabel Pemanfaatan aplikasi learning management system (X)

Secara keseluruhan variabel perilaku belajar mahasiswa (X) memberikan kontribusi sebesar 23,97\% terhadap kepuasan belajar mahasiswa. Nilai ini sudah 
dioptimalkan dengan baik. Akan lebih baik bila mahasiswa Jurusan Teknik Informatika ITP mampu mengoptimalkan pemanfaatan aplikasi learning $(\mathrm{X})$ dengan lebih baik lagi agar dapat membantu mahasiswa dalam perkuliahan.

b. Variabel Kepuasan Belajar (Y)

Hasil penelitian ini menemukan bahwa kontribusi motivasi belajar $\left(\mathrm{X}_{1}\right)$ dan pemanfaatan aplikasi learning management system $\left(\mathrm{X}_{2}\right)$ secara bersama-sama terhadap kepuasan belajar mahasiswa (Y) sebesar 41,4 $\%$. Angka ini memberikan indikasi bahwa masih terdapat $58,6 \%$ membutuhkan perhatian mahasiswa Jurusan Teknik Informatika ITP untuk lebih fokus terhadap seluruh kegiatan pendidikan. Bila terdapat hal-hal yang berhubungan dengan motivasi belajar dan pemanfaatan aplikasi learning management system yang dapat menurunkan kepuasan belajar mahasiswa, perlu untuk ditingkatkan dan ditanggapi secara cepat, sehingga motivasi belajar dan pemanfaatan aplikasi learning management system akan tetap mendukung peningkatan kepuasan belajar mahasiswa Jurusan Teknik Informatika ITP dilakukan dengan meningkatkan motivasi belajar serta mengoptimalkan pemanfaatan aplikasi learning management system.

\section{DAFTAR PUSTAKA}

Agus Lukman Hakim, Munzil dan Parlan. (2013). "Pengembangan Media Pembelajaran Berbasis Learning Management System (LMS) Pada Materi Senyawa Karbon Untuk SMA Kelas XII." Jurnal Jurusan Kimia FMIPA Universitas Negeri Malang. Hlm. 1-2

Basori. (2013). "Pemanfaatan Social Learning Network "Edmodo"

Dalam Membantu Perkuliahan Teori Bodi Otomotif Di Prodi PTM JPTK FKIP UNS.” Jurnal Pend.Teknik Informatika Komputer, Jurusan Pendidikan Teknik Kejuruan, FKIP,UNS. HIm. 2

Depdikbud. (2003). Undang-undang RI NO.20 Tahun 2003 tentang Sistem Pendidikan Nasional. Jakarta: Lemhanas.

Gartika dan Rita, (2013). E-learning Pembelajaran Jarak Jauh untuk SMA. Bandung:Yrama Widya.

Hamzah B. Uno. (2011). Teori Motivasi dan Pengukurannya: Analisis di Bidang 
Pendidikan. Jakarta: Bumi aksara

Rusman. (2013). Belajar dan

Pembelajaran Berbasis Komputer

Mengembangkan Profesionalisme

Guru Abad 21. Bandung:

ALFABETA.

Suharsimi Arikunto. (1998). Prosedur

Penelitian. Jakarta : Rineka Cipta.

Suharsimi Arikunto. (2002). Prosedur

Penelitian. Jakarta : Rineka Cipta.

Suharsimi Arikunto. (2010). Prosedur

penelitian : Suatu Pendekatan

Praktik. (Edisi. Revisi). Jakarta :

PT. Rineka Cipta.

Slameto. (2010). Belajar dan Faktor-

faktor Yang Mempengaruhinya.

Jakarta: Rineka Cipta.

Sugiyono, (2007). Metode Penelitian

Kuantitatif, Kualitatif, dan $R \& D$.

Bandung: Alfabeta.

Sugiyono, (2013). Metode Penelitian

Kuantitatif, Kualitatif, dan $R \& D$.

Bandung: Alfabeta. 